\title{
Heavy metal investigation in River Siranat Khaki site Khyber Pakhtunkhwa Pakistan
}

\author{
Khalid Usman ${ }^{* 1}$, RizwanUllah Khan ${ }^{2}$, Hameed Ur Rehman ${ }^{2}$, Wajid Ullah', \\ Muhammad Naseem ${ }^{3}$, Muhammad Ayub Babar ${ }^{4}$, Muhammad Asif ${ }^{\mathfrak{s}}$, Ehsan Ullah ${ }^{6}$, \\ Muhammad Arif ${ }^{7}$ Muhammad Ayub ${ }^{8}$, Muhammad Tariq ${ }^{9}$ Khalid Pervaiz ${ }^{10}$, \\ InayatUllah Malik ${ }^{11}$
}

'Department of Zoology, Hazara University Mansehra, Khyber Pakhtunkhwa, Pakistan

${ }^{2}$ Department of Chemistry, Kohat University of Science $\Xi$ Technology, Kohat, KP, Pakistan

${ }^{3}$ Directorate of Agriculture Research, Potato Seed Production Pishin, Quetta, Pakistan

${ }^{\top}$ Directorate of Vegetable Seed Production, Agriculture Research Institute, Quetta, Pakistan

${ }^{5}$ Directorate of Cereal Crops, Agriculture Research Institute Sariab Road, Quetta Pakistan

${ }^{6}$ Rural Development Academy Quetta, Balochistan, Pakistan

${ }^{7}$ Directorate of Pulses, Agriculture Research Institute, Quetta, Pakistan

${ }^{8}$ Directorate of Oilseed Crops, Agriculture Research Institute, Quetta, Pakistan

${ }^{9}$ Directorate of Special Crops, Agriculture Research Institute, Quetta, Pakistan

${ }^{10}$ Fisheries Research \& Training Institute, Government of the Punjab, Lahore, Pakistan

${ }^{11}$ Department of Biological Sciences, Sub Campus Mianwali, University of Sargoda, Pakistan

Article published January 26, 2019

Key words: Siran, Khaki, Pollution, Metals, Sampling, Range.

\begin{abstract}
The present investigation was conducted to evaluate the amount of heavy metals from River Siran at Khaki site Khyber Pakhtunkhwa, Pakistan. The chosenheavy metals were $\mathrm{Zn}, \mathrm{Cu}, \mathrm{Cd}, \mathrm{Pb}, \mathrm{Cr}$ and $\mathrm{Mn}$ correspondingly. In the current survey,the concentration of heavy metals examined were Zn 1.14-1.85 ppm; $\mathrm{Cu}$ 1.04-1.25 ppm; Cd 0.02-1.35 ppm; Pb 0.05-1.27 ppm; Cr 0.04-0.16 ppm and Mn 0.06-0.08 ppm respectively. In the present research $\mathrm{Cu}, \mathrm{Cd}, \mathrm{Pb}$ and $\mathrm{Cr}$ were found above the permissible ranges while $\mathrm{Zn}$ 1.13-1.88 and Mn 0.01-0.04 were lies within the permissible limits.
\end{abstract}

*Corresponding Author: Khalid Usman $₫$ khalidusmankhattak1985@gmail.com 


\section{Introduction}

Among environmental pollutants, metals are of particular concern, due to their potential toxic effect and ability to bioaccumulate in aquatic ecosystems (Censi et al., 2006). Heavy metals including both essential and non-essential elements have a particular significance in ecotoxicology, since they are highly persistent and all have the potential to be toxic to living organisms (Storelli et al., 2005). The most common heavy metal pollutants are cadmium (Cd), chromium $(\mathrm{Cr})$, copper $(\mathrm{Cu})$, nickel $(\mathrm{Ni})$, lead $(\mathrm{Pb})$, manganese (Mn) and zinc ( $\mathrm{Zn})$. Their source of entry into the aquatic system could either be single, identifiable or dispersed (often difficult to identify). The fact that heavy metals cannot be decomposed through biological degradation and have the ability to accumulate in the environment (Asaolu and Olaofe, 2005; Olowuet al., 2010). After decades of rapid urbanization, population growth and industrialization, developing countries are now home to many of the world's most critical air, water and solid waste problems. Early studies have identified the rise in the pollution of particular heavy metals in freshwater systems around the world, particularly in rivers. The pollution has mainly been caused by industrial processes and industrial waste, typically from rubber and oil palm mills (Tariq et al., 1996). Heavy metal concentrations in aquatic ecosystems are usually monitored by measuring their concentrations in water, sediments and biota (Camusso et al., 1995), which generally exist in low levels in water and attain considerable concentration in sediments and biota (Namminga and Wilhm, 1976). Trace elements are chemical elements that are required in a very minute amount for the proper growth, development and human physiology. They are called heavy metals because their densities greater than $5 \mathrm{~g} / \mathrm{cm} 3$. However these essential trace elements be-come poisonous when their concentration becomes extreme (Dao et al., 2008). Contamination of surface water by heavy metals is a serious ecological problem as some of them like $\mathrm{Hg}$ and $\mathrm{Pb}$ are toxic even at low concentrations, are non-degradable and can bioaccumulate through food chain.
Though some metals like $\mathrm{Fe}, \mathrm{Cu}$ and $\mathrm{Zn}$ are essential micronutrients, they can be detrimental to the physiology of the living organisms at higher concentrations (Kar et al., 2008; Nair et al., 2010). Heavy metals are produced from a variety of natural and anthropogenic sources, they are indeed an intrinsic natural constituents of our environment. In fluvial environments, however, metal pollution can result in from direct atmospheric deposition, geologic weathering or through the discharge of agricultural, municipal or industrial waste products (Dawson and Macklin, 1998). Heavy metals were recorded by Usman et al. (2017d) to study the water quality of the River Kabul at Dalda Oil Mill Nowshera Khyber Pakhtunkhwa, Pakistan. Water samples were collected from three different sites along the course of the River Kabul at Dalda Oil Mill Nowshera. The ranges of the heavy metals obtained during the present research were $\mathrm{Zn}$ 2.11-2.8 ppm; $\mathrm{Cu}$ 0.3-2.23 ppm; Cd 0.12-0.88 ppm; Pb 0.02-2.06 ppm; Cr 0.02$0.16 \mathrm{ppm}$ and Mn 0.41.11 ppm respectively. A study was conducted by Usman et al. (2017e) to analyze the concentration of toxic pollutant. In this study the amount of heavy metals recorded were $\mathrm{Zn} \mathrm{1.19-1.7}$ ppm; Cu 0.13-0.75 ppm; Cd 0.02-0.32 ppm; pb 1.010.03 ppm; Cr 0.00-0.00 ppm and Mn 0.01-0.03 ppm respectively. Measurement of heavy metals was conducted by Fawad et al to know the rate of bioaccumulation of Chromium (Cr (III) in the gills, intestine, and skin and its acute toxicity to goldfish (Carassiusauratus) fingerlings. The result shows that the rate of accumulation of chromium in Gills > Intestine > Skin of gold fish (Fawad et al., 2007).Concentration of heavy metals was analyzed by Usman et al. (2017c) in the River Kabul Shah Alam tributary, Peshawar Khyber Pakhtunkhwa, Pakistan. The concentration of the heavy metals were $\mathrm{Zn} \mathrm{1.2-}$ 2.0 ppm; $\mathrm{Cu}$ 0.17-1.48 ppm; Cd 0.2-0.69 ppm; $\mathrm{Pb}$ 1.01-1.23 ppm; Cr 0.04-2.01 ppm and Mn 0.01-0.82 ppm respectively. Evaluation of heavy metals were carried out by Afridi et al in the common carp (Cypriniuscarpio) collected from two different water bodies the Tarbela dam, District Haripur, and River Soan District Rawalpindi Pakistan. 
The concentration of detected metals found in different tissues of same species varied for $\mathrm{Mn}$ : 0.434.96, Ni: $0.49-1.60, \mathrm{Cd}: 0.06-0.08, \mathrm{Cu}: 0.36-$ o.81, Pb: $0.50-0.74$, Se: $6.17-17.05, \mathrm{Zn}: 0.59-3.74$ $\mu \mathrm{g} / \mathrm{g}$ wet wt (Afridi, 2017). Amount of heavy metals were analyzed by Usman et al. (2017a) in different sites of River Kabul on Rohu, Labeorohita (Hamilton). As a result of accumulation of heavy metals in fish bodies, various diseases occurred which ultimately declined their population.

It is suggested that if the proper, timely remedial measures are not adopted, the situation will be aggravated and may cause the loss of precious fish diversity in the country. Hence, to overcome this serious problem industries discharge should be cleaned before entering to the River and properly time to time Fish fauna should be checked out. Quantity of health hazard metals was detected by Usman et al. (2017b) in natural waters of river Kabul,
Khyber Pakhtunkhwa Province, Pakistan. The concentrations of the metals recorded were in the range as: $\mathrm{Pb}$ 0.06-4.41 ppm; $\mathrm{Zn}$ 4.11-7.11 ppm; Cd 0.42-1.46 ppm; Cu 1.07-3.86 ppm; Mn 0.06-2.11 ppm and $\mathrm{Cr} 0.05^{-2.11} \mathrm{ppm}$. The aim of the current research work was to find out the heavy metal in River Siranat Khaki site Khyber Pakhtunkhwa Pakistan

\section{Materials and methods}

Study area

Khaki is one of the most beautiful place of Mansehra Khyber Pakhtunkhwa, Pakistan. Geographical Khaki is situated in Mansehra. Its coordinates is $34^{\circ} 24^{\prime} \mathrm{O}^{\prime \prime}$ North, $73^{\circ} 8^{\prime} \mathrm{o}^{\prime \prime}$ East. Climate of this area is warm and temperate. The rainfall in Khaki is significant, with precipitation even during the driest month.

The average annual temperature remains $18.5{ }^{\circ} \mathrm{C}$. In a year, the average rainfall is $1445 \mathrm{~mm}$.

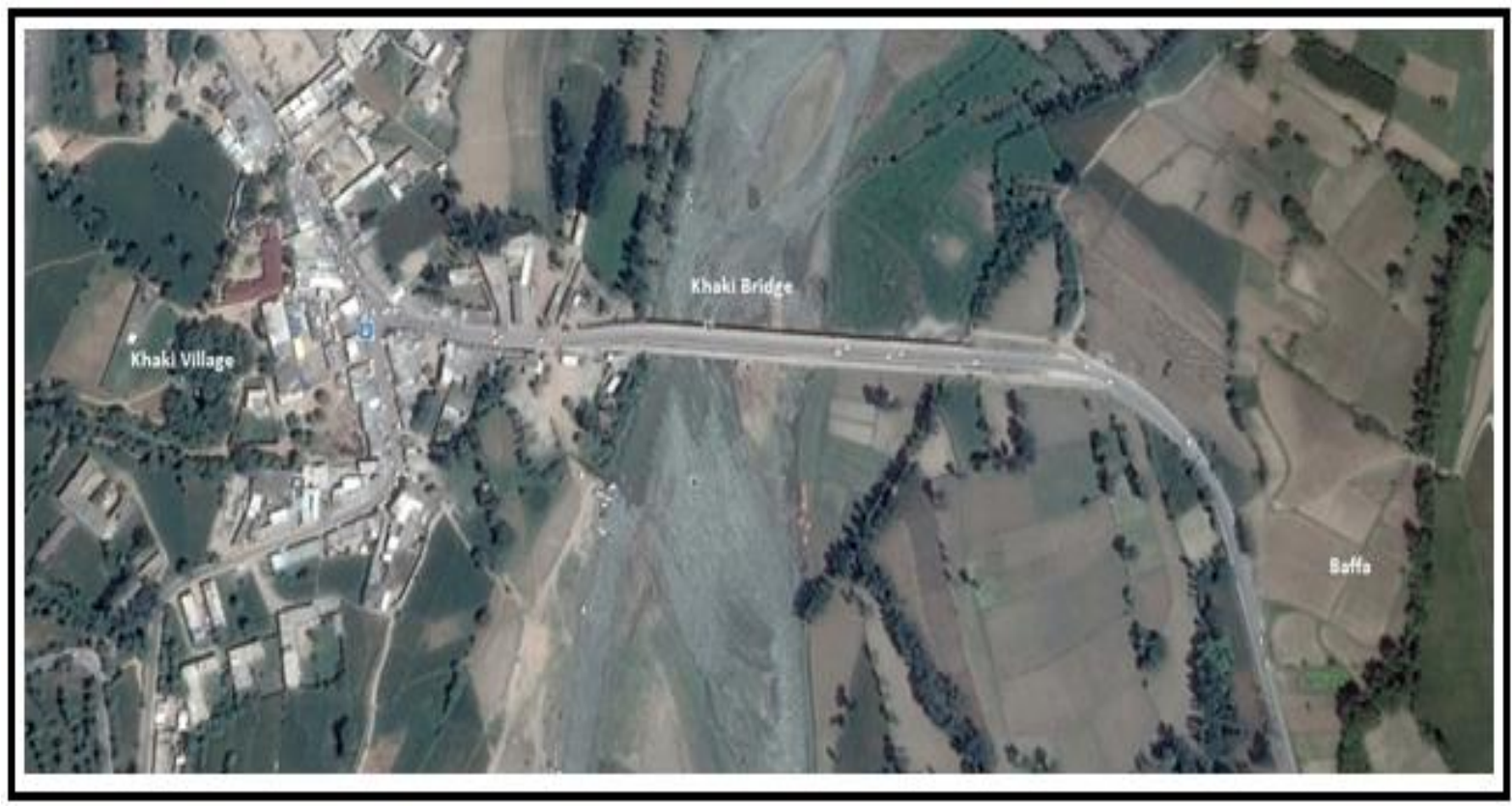

Fig. 1. Map of Khaki site at River Siran Khyber Pakhtunkhwa, Pakistan.

\section{Sampling of water}

Water samples were stored in clean and dry plastic bottles with screw caps and labeled. The freshly collected samples were analyzed for Heavy metals analysis at GC University Faisalabad lab by using atomic absorption.

\section{Method for preparation of stock solution}

The stock solution was prepared as $1000 \mathrm{ppm}=1000$ $\mathrm{mg} / \mathrm{l}$. Then $100 \mathrm{ppm}$ solution was prepared from stock solution using serial dilution equation of $\mathrm{C} 1 \mathrm{~V} 1=$ $\mathrm{C} 2 \mathrm{~V} 2$. 


\section{Determination of heavy metals in water}

The water samples were first filtered with the help of filter paper and then taken in $250 \mathrm{ml}$ of glass bottles and subjected to the atomic absorption spectrophotometer $(\mathrm{Zn}, \mathrm{Cu}, \mathrm{Cd}, \mathrm{Mn}, \mathrm{Cr}, \mathrm{Pb})$ at $\mathrm{GC}$ University Faisalabad lab.

\section{Results and discussion}

In the present study, the amount of heavy metals analyzed were $\mathrm{Zn}$ 1.14-1.85 ppm; Cu 1.04-1.25 ppm; Cd 0.02-1.35 ppm; Pb 0.05-1.27 ppm; Cr 0.04-0.16 ppm and Mn 0.06-0.08 ppm respectively. According WHO the $\mathrm{Cu}, \mathrm{Cd}, \mathrm{Pb}$ and $\mathrm{Cr}$ were found above the standard level while Zn 1.13-1.88 and Mn 0.01-0.04 were lies within the permissible ranges.Usman et al., 2018 conducted study to find out concentration of heavymetals in River Indus at Thakot Khyber Pakhtunkhwa, Pakistan. Heavy metals concentration obtained was $\mathrm{Zn}$ 1.15-1.86 ppm; Cu 1.06-1.25 ppm; Cd 0.05-1.39 ppm; Pb 0.03-1.22 ppm; Cr 0.04-0.13 pm and Mn 0.02-0.06 ppm respectively.

In this examination $\mathrm{Cu}, \mathrm{Cd}, \mathrm{Pb}$ and $\mathrm{Cr}$ were above the permissible limits. Usman et al. (2017e) work on River Kabul at Cantt area Nowshera to evaluate heavy metals.

Table 1. Concentration of heavy metals (ppm) in River Siran at Khaki site KP, Pakistan.

\begin{tabular}{lccccc}
\hline S.No & Metals & U.S & M.P & D.S & Permissible limits WHO \\
\hline 1 & $\mathrm{Zn}$ & 1.14 & 1.85 & 1.34 & $5.0 \mathrm{mg} / \mathrm{l}$ \\
2 & $\mathrm{Cu}$ & 1.04 & 1.25 & 1.07 & $0.05 \mathrm{mg} / \mathrm{l}$ \\
3 & $\mathrm{Cd}$ & 0.02 & 1.35 & 0.16 & $0.05 \mathrm{mg} / \mathrm{l}$ \\
4 & $\mathrm{~Pb}$ & 0.05 & 1.27 & 0.15 & $0.05 \mathrm{mg} / \mathrm{l}$ \\
5 & $\mathrm{Cr}$ & 0.04 & 0.16 & 0.03 & $0.05 \mathrm{mg} / \mathrm{l}$ \\
6 & $\mathrm{Mn}$ & 0.06 & 0.03 & 0.08 & $50-70 \mathrm{mg} / \mathrm{l}$ \\
\hline
\end{tabular}

The metals which were recorded in the present study were $\mathrm{Zn} \mathrm{1.13-1.85} \mathrm{ppm;} \mathrm{Cu} \mathrm{1.02-1.21} \mathrm{ppm;} \mathrm{Cd} \mathrm{0.03-}$ 1.32 ppm; pb 0.04-1.23 ppm; Cr 0.010.16 ppm and Mn 0.00-0.00 ppm respectively. In a research study demonstrated by Usman et al. (2018f) to estimate the amount of heavy metals in the water of River Kabul at Jehangira Lower Khyber Pakhtunkhwa, Pakistan. The highest concentration of the heavy metals was found $\mathrm{Cu}$ 0.2-1.66, Cd 0.06-0.96, Pd 0.02-1.1, $\mathrm{Cr}$ 0.01-0.06 while the lowest concentration was found Mn 0.11-0.23 and zinc 1.132.37 respectively. In a study carried out to assess concentration of heavy metals in River Indus at Pattan site Khyber Pakhtunkhwa, Pakistan.

Water samplings were carried out from the three selected sites of the River at Pattan site like The Upstream, Mid-Point and Downstream. The amount of heavy metals obtained was $\mathrm{Zn}$ 1.16-1.89 ppm; $\mathrm{Cu}$ 1.04-1.25 ppm; Cd 0.56-1.32 ppm; Pb 0.07-1.27 ppm; $\mathrm{Cr}$ 0.02-0.18 ppm and $\mathrm{Mn}$ 0.04-0.09 ppm respectively (Usman et al., 20180). A survey was carried out by Usman et al (2017g) to find out the concentration of heavy metals in Jhanjira Upper site of the River Kabul Khyber Pakhtunkhwa, Pakistan. The results obtained from the current study were in the range of $\mathrm{Zn}$ 1.11-1.97 ppm; Cu 1.05-1.63 ppm; Cd 0.11-0.89 ppm; Pb 0.07-1.07 ppm; Cr 0.01-0.11 ppm and $\mathrm{Mn}$ 0.02-0.28 ppm respectively.A study was conducted to evaluate the concentration of heavy metals in River Indus at Biliani site Khyber Pakhtunkhwa, Pakistan. For this purpose water samples were collected from three sites of the River i.e. upstream, midpoint and downstream respectively. The concentration of heavy metals such as cadmium, chromium, copper, manganese, lead, and zinc was recorded $\mathrm{Zn}$ 1.18-1.71 ppm; $\mathrm{Cu}$ 1.05-1.26 ppm; Cd 0.06-1.38 ppm; Pb 0.05-1.24 ppm; Cr 0.04-0.19 ppm and Mn 0.03-0.08 ppm respectively (Usman et al., 2018n). Analysis of heavy metals was determined by Usman et al. (2017h) to explore the amount of heavy metals in River Kabul at Khairabad water KP, 
Pakistan. Concentration of water samples was $\mathrm{Zn}$ 1.5-1.59 ppm; Cu 1.15-1.94 ppm; Cd 0.02-0.05 ppm; $\mathrm{Pb}$ 0.15-0.73 ppm; Cr 0.01-0.02 ppm and Mn 0.07$0.21 \mathrm{ppm}$ respectively.A survey was conducted by Usman et al. (2018m) to evaluate concentration of heavy metals in River Dor at Mankarai Khyber Pakhtunkhwa, Pakistan. Heavy metals obtained were Zn 1.13-1.86 ppm; Cu 1.03-1.25 ppm; Cd 0.04-1.35 ppm; Pb 0.05-1.28 ppm; Cr 0.05-0.17 ppm and $\mathrm{Mn}$ 0.03-0.07 ppm respectively. Assessment of heavy metals were carried out by Usman et al. (2017i) to examine the concentration of health hazard toxic metals in in River Kabul at KhazanaSuger Mill Peshawar KP, Pakistan. Heavy metals concentration obtained from the present study was Zn 1.13-201 ppm; $\mathrm{Cu}$ 0.55-0.9 ppm; $\mathrm{Cd}$ 0.02-1.22 ppm; $\mathrm{Pb}$ 1.231.84 ppm; Cr 0.21-1.2 ppm and Mn 0.02-0.05 ppm respectively.An Investigation was carried outby Usman et al. (2018l) to explore the quantity of health hazard toxic metals in River Dor at Jama site Khyber Pakhtunkhwa, Pakistan.

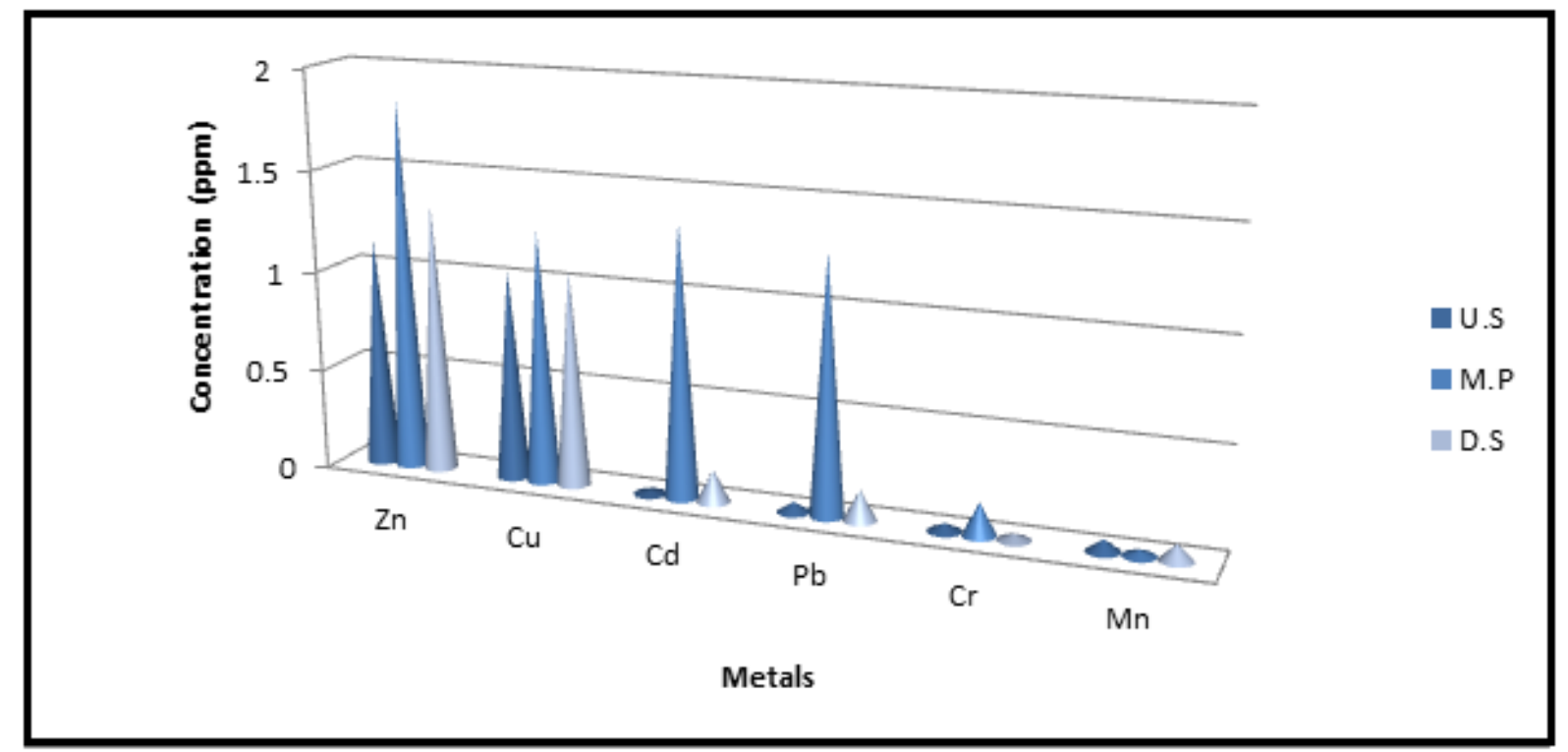

Fig. 2. Concentration of heavy metals (ppm) in River Siran at Khaki site site KP, Pakistan. U.S (Upstream); M.P (Mid-point); D.S (Downstream).

The concentration of the toxic heavy metals obtained was $\mathrm{Zn}$ 1.12-1.86 ppm; $\mathrm{Cu}$ 1.03-1.24 ppm; Cd 0.041.35 ppm; Pb 0.05-1.28 ppm; Cr 0.02-0.17 ppm and Mn 0.01-0.03 ppm respectively. A research work was conducted by Usman et al. (2017j) to estimate the amount of heavy metals in River Kabul at Kond Marble factory KP, Pakistan. The concentration of heavy metals obtained was $\mathrm{Zn}$ 1.2-231 ppm; $\mathrm{Cu}$ 0.31.89 ppm; Cd 0.13-0.75 ppm; Pb 1.13-0.96 ppm; $\mathrm{Cr}$ 0.01-0.02 ppm and Mn 0.11-0.44 ppm respectively. Atlas et al. (2017) find out the amount of heavy metals in River Kabul at Sardaryab KP, Pakistan. The heavy metals analyzed in the present research were in the range of $\mathrm{Zn} 1.14-1.86 \mathrm{ppm}$; $\mathrm{Cu}$ 1.03-1.22 ppm; Cd 0.12-0.89 ppm; $\mathrm{Pb}$ 0.08-1.08 ppm; $\mathrm{Cr}$ 0.02-0.12 ppm and Mn 0.03-0.29 ppm respectively.
A research study was conducted by Farhanet al. (2016) to determine the concentration of some heavy metals in water and soil samples of four different dams located in the area of Karak, KPK, Pakistan. Heavy metals analyzed in water and soil samples of all the four dam's indicated that among the seven heavy metals tested, Fe was maximum in concentration, followed by $\mathrm{Zn}, \mathrm{Cu}, \mathrm{Pb}, \mathrm{Ni}, \mathrm{Cr}$ and $\mathrm{Cd}$. The sequence of heavy metals decreased in Zebi dam as $\mathrm{Fe}>\mathrm{Cu}>\mathrm{Zn}>\mathrm{Pb}>\mathrm{Ni}>\mathrm{Cr}>\mathrm{Cd}$, in the sarki dam as $\mathrm{Fe}>\mathrm{Cu}>\mathrm{Zn}>\mathrm{Pb}>\mathrm{Cd}>\mathrm{Cr}>\mathrm{Ni}$, in the sharki dam as $\mathrm{Fe}>\mathrm{Zn}>\mathrm{Cu}>\mathrm{Pb}>\mathrm{Ni}>\mathrm{Cd}>\mathrm{Cr}$, and in the Changos dam as $\mathrm{Fe}>\mathrm{Zn}>\mathrm{Pb}>\mathrm{Cu}>\mathrm{Cd}>\mathrm{Cr}>\mathrm{Ni}$ respectively. A survey was carried out by Rehmnaet al. (2015) on Bannu Dam's and Damai Stream during Breeding Season of Fishes. 
The order of heavy metals concentration in water and soil of damai stream and dam's was: Fe $53.17 \pm 0.2 \mathrm{mg} / \mathrm{L}$ (Gomalzam dam soil sample) and $46.12 \pm 0.1 \mathrm{mg} / \mathrm{L}$ (Gomalzam dam water sample), $\mathrm{Pb}$ $5.53 \pm 0.32 \mathrm{mg} / \mathrm{L}$ (Gomalzam dam water sample) and $5.097 \pm 0.17 \mathrm{mg} / \mathrm{L}$ (Gomalzam dam soil sample), $\mathrm{Cu}$ $6.05 \pm 0.11 \mathrm{mg} / \mathrm{L}$ (Gomalzam dam water sample) and $3.50 \pm 0.01 \mathrm{mg} / \mathrm{L}($ Barganatu dam soil sample),Zn $3.38 \pm 0.03 \mathrm{mg} / \mathrm{L}($ Damai stream soil sample) and $2.27 \pm 0.01 \mathrm{mg} / \mathrm{L}($ Baran dam soil sample), $\mathrm{Ni}$ $0.77 \pm 0.01 \mathrm{mg} / \mathrm{L}$ (Baran dam water sample) and $0.54 \pm 0.01 \mathrm{mg} / \mathrm{L}($ Baran dam soil sample), $\mathrm{Cd}$ $0.67 \pm 0.01 \mathrm{mg} / \mathrm{L}$ (Damai stream soil sample) and $0.23 \pm 0.02 \mathrm{mg} / \mathrm{L}$ (Damai stream water sample), $\mathrm{Cr}$ $0.12 \pm 0.01 \mathrm{mg} / \mathrm{L}$ (Barganatu dam soil sample) and 0.08 $\pm 0.03 \mathrm{mg} / \mathrm{L}($ Baran dam water sample).A research work was conducted by Usman et al. (2018k) to find out the concentration of heavy metals in River Dor at Dobandi site Khyber Pakhtunkhwa, Pakistan. In this study three sampling stations (Upstream, MidPoint and Downstream) were selected in River Dor at Dobandi site which were away from one another 100 meter distance. The concentration of hazard heavy metals recorded were $\mathrm{Zn}$ 1.151.89 ppm; Cu 1.05-1.27 ppm; Cd 0.07-1.39 ppm; pb 0.06-1.27 ppm; Cr 0.03$0.19 \mathrm{ppm}$ and $\mathrm{Mn}$ 0.03-0.05 ppm respectively. Another research was conducted by Rehman et al. (2016) to evaluate heavy metal of Molluska Shell, Water and Soil Collected from Darmalak Dam, Tehsil Lachi District Kohat. The homogeneity, samples Cr not present. But tissue samples having the diverge the concentration as well as order. The high concentration of heavy metals found in the sediment is due to the anthropogenic inputs and fishing activity.

\section{Conclusion}

The current survey was conducted in River Siran at Khaki site Khyber Pakhtunkhwa Pakistan to assess the concentration of heavy metals. From the current results it can be concluded that due to heavy metals toxicity water quality of this sampling station was not suitable.

\section{Acknowledgement}

Immense Thankful to Dr. Khalid Pervaiz and Dr. InayatUllah Malik. I am greatly thankful to Hameed Ur Rehman (Department of Chemistry). I am also thankful to my brother Dr. Wahid Raza (Department of Management Sciences ICUP) who helps me throughout in my research work.

\section{References}

Afridi AJ, Zuberi A, Rehman HU, Khan A, Saeed K, Achakzai WM, Saddozai S, Usman, K, Ateeq M, Akbar NU. 2017. Effect of the aquatic environment of different water bodies on metal contents of common carp (Cypriniuscarpio) collected from two different water bodies. Journal of Entomology and Zoology Studies 5(1), 388-399.

Asaolu SS, Olaofe O. 2005. Biomagnification of some heavy and essential metals in sediment, fishes and crayfish from Ondo State Coastal Region, Nigeria. Pakistan Journal of Scientific and Industrial Research 48, 96-102.

Atlas A, Usman K, Rehman HU, Khudadad S, Munawar A, Rab A, Khan MI, Gul M, Pervaiz K. 2017. Analysis of heavy metals in river Kabul at Sardaryab Khyber Pakhtunkhwa, Pakistan. Journal of Entomology and Zoology Studies 5(6), 14-16.

Camusso M, Vigano L, Baitstrini R. 1995. Bioaccumulation of trace metals in rainbow trout. Ecotoxicology Environmental Safety 31, 133-141.

Censi P, Spoto SE, Saiano F, Sprovieri M, Mazzola S, Nardone G, Di Geronimo SI, Punturo R, Ottonello D. 2006. Heavy metals in coastal water systems. A case study from the northwestern Gulf of Thailand. Chemosphere 64, $1167-1176$

Dawson EJ, Macklin MG. 1998. Speciation of heavy metals in floodplain and flood sediments: a reconnaissance survey of the Aire Valley, Wet Yorlshire, Great Britain. Environ. Geo chem Health 20, $67-76$ 
Farhan Rehman HU, Bibi I, Zakir M, Ullah N, Waheed MA, Haleem S, Zarin K, Yasin N, Nisa I. 2016. Heavy metal analysis of water and soil of district Karak dams during fish breeding season, KPK, Pakistan. Journal of Entomology and Zoology Studies 4(3), 91-93.

Fawad M, Yousafzai AM, Haseeb A, Rehman HU, Afridi AJ, Akhtar NA, Saeed K, Usman K. 2017. Acute toxicity and bioaccumulation of chromium in gills, skin and intestine of goldfish (Carassiusauratus). Journal of Entomology and Zoology Studies 5(1), 568-571.

Gao S, Jin Y, Unverzagt FM, Hall KS. 2008. Trace element levels and cognitive function in rural elderly Chinese. Journal of Gernotology and Medical Science 63(6), 635-641.

Kar D, Sur P, Mandal SK, Saha T, Kole RK. 2008. Assessment of heavy metal pollution in surface water. International Journal of Environmental Science and Technology 5(1), 119-124.

Nair IV, Singh K, Arumugam M, Gangadhar K, Clarson D. 2010. Trace metal quality of Meenachil River at Kottayam, Kerala (India) by principal component analysis. World Applied Science Journal 9(10), 1100-1107.

Namminga HN, Wilhm J. 1976. Effects of high discharge and an oil refinery cleanup operation bon heavy metals in water and sediments in Skeleton Creek. Proceedings of the Oklahoma Academy of Science 56, 133-138.

Olowu RA, Ayejuyo Oo, Adewuyi Go, Adejoro, IA, Denloye AAB, Babatunde AO, Ogundajo AL. 2010. Determination of Heavy Metals in Fish Tissues, Water and Sediment from Epe and Badagry Lagoons, Lagos, Nigeria. E-Journal of Chemistry 7, 215-221.

www.e-journals.net
Rehman HU, Ismail M, Khan RU, Haq ZU, Farhan Zakir M, Zahoor B, Ahmad I, Awais S. 2015. Heavy Metals Analysis of Bannu Dam's and Damai Stream During Breeding Season of Fishes. World Applied Sciences Journal 33(12), 1842-1845.

Rehman HU, Khan RU, Sajed M, Akbar NU, Rehman JU, Awais S, Ahmad I, Maqbool S, Ullah N, Andaleeb H. 2016. Estimation of Heavy Metal of Molluska Shell, Water and Soil Collected from Darmalak Dam, Tehsil Lachi District Kohat. World Journal of Zoology 11(1), 01-05.

Storelli MM, Storelli A, D'ddabbo R, Marano C, Bruno R, Marcotrigiano GO. 2005. Trace elements in loggerhead turtles (Carettacaretta) from the eastern Mediterranean Sea: Overview and evaluation. Environmental Pollution 135, 163-170.

Tariq J, Ashraf M, Afzal M. 1996. Pollution status of the Indus River, Pakistan, through heavy metal and macronutrient contents of fish, sediment and water. Water Research 3o(6), 1337-1344.

Usman K, Rehman HU, Pervaiz K, Malik IU, Jawad SM, Shah W, Khan SA, Akhtar, H, Shahid R, Mehmood A. 2018. Assessment of heavy metals in River Dor at Dobandi Khyber Pakhtunkhwa, Pakistan. Journal of Biodiversity and Environmental Sciences 12(5), 2222-3045.

Usman K, Rehman HU, Pervaiz K, Malik IU, Jawad SM, Shah W, Azizullah, Mehmood A, Hussain R, Rehman FU. 2018. Analysis of heavy metals in River Indus at Biliani Khyber Pakhtunkhwa, Pakistan Journal of Biodiversity and Environmental Sciences 12(5), 231-236.

Usman K, Rehman HU, Pervaiz K, Malik IU, Jawad SM, Shah W, Azizullah, Mehmood A, Hussain R, Rehman FU. 2018. Contamination of heavy metals in River Indus at Thakot Khyber Pakhtunkhwa, Pakistan. International Journal of Biosciences 12(5), 201-205. 
Usman K, Rehman HU, Pervaiz K, Malik IU, Jawad SM, Shah W, Mehmood A, Hussain R, Rehman FU. 2018. Investigation of heavy metals in River Dor at Mankarai Khyber Pakhtunkhwa, Pakistan. International Journal of Biosciences 12(5), 215-220.

Usman K, Rehman HU, Pervaiz K, Malik IU, Jawad SM, Shah W, Mehmood A, Hussain R, Rehman FU. 2018. Investigation of heavy metals in River Dor at Mankarai Khyber Pakhtunkhwa, Pakistan International Journal of Biosciences 12(5), 215-220.

Usman K, Rehman HU, Pervaiz K, Malik IU, Rehman FU, Hussain R, Shah W, Jawad SM, Mehmood A. 2018. Estimation of heavy metals in River Indus at Pattan Khyber Pakhtunkhwa, Pakistan Journal of Biodiversity and Environmental Sciences 12(5), 278-283.

Usman K, Nisa ZU, Gul S, Gul S, Rehman HU, Asad M, Waqar M, Ullah, Ishaq HK. $2017 \mathrm{c}$. Contamination of Heavy metals in River Shah Alam Peshawar: (A tributary of River Kabul) Khyber Pakhtunkhwa Pakistan. Journal of Entomology and Zoology Studies 5(5), 510-512.

Usman K, Rehman HU, Adeel S, Shah NA, Shah A, Pervaiz K, Saeed N, Mussabeha. 2017. Heavy Metals Accumulation in Labeo rohita (Hamilton) of River Kabul, KPK, Pakistan. Biological Forum - An International Journal 9(1): 01-07.

Usman K, Rehman HU, Adeel S, Shah W, Pervaiz K, Ullah Z, Ullah R, Arsalan M. 2017 An Investigation on the toxicity of some trace metals in river Kabul, Khyber Pakhtunkhwa Province of Pakistan. Biological Forum - An International Journal 9(1), 95-99.

Usman K, Rehman HU, Khudadad HS, Pervaiz K, Ahmad N, Bilal M, Hussain ST, Jawad SM, Khan M, Akbar MU. 2017d. Concentration of heavy metals in River Kabul at Dalda Oil Mill Nowshera Khyber Pakhtunkhwa, Pakistan. Journal of Entomology and Zoology Studies 5(6), 2395-2397.
Usman K, Rehman HU, Khudadad HS, Pervaiz K, Ali SZUA, Maqsood MJ, Jawad SM, Din AU, Ihtesham Y. 2018f. Investigation of heavy metals in River Kabul at Jehangira Lower Khyber Pakhtunkhwa, Pakistan. Journal of Entomology and Zoology Studie 6(1), 100-102.

Usman K, Rehman HU, Khudadad HS, Pervaiz K, Ali, SZUA, Maqsood MJ, Jawad SM, Nazir R, Ihtesham Y. 2017i. Evaluation of heavy metals in River Kabul at Khazana Sugar Mill Peshawar Khyber Pakhtunkhwa, Pakistan. Journal of Entomology and Zoology Studies 5(6), 2417-2419.

Usman K, Rehman HU, Khudadad HS, Pervaiz K, Ali SZUA, Maqsood MJ, Jawad SM, Nazir, R, Ihtesham Y. 2017j. Exploration of heavy metals in River Kabul at marble factory Kond Khyber Pakhtunkhwa, Pakistan. Journal of Entomology and Zoology Studies 5(6), 2272-2274.

Usman K, Rehman HU, Khudadad S, Pervaiz K, Ahmad N, Bilal M, Hussain ST, Jawad SM, Khan M, Ali M. 2017e. Estimation of heavy metals in River Kabul at Cantt area Nowshera Khyber Pakhtunkhwa, Pakistan. Journal of Entomology and Zoology Studies 5(6), 2275-2277.

Usman K, Rehman HU, Khudadad S, Pervaiz K, Ahmad N, Bilal M, Hussain ST, Jawad SM, Khan M, Akbar MU. 2017g. Heavy metals analysis in River Kabul at Jhangira Upper Khyber Pakhtunkhwa, Pakistan. Journal of Entomology and Zoology Studies 5(6), 2485-2487.

Usman K, Rehman HU, Khudadad S, Pervaiz K, Ali SZUA, Maqsood MJ, Jawad SM, Din AU, Ihtesham Y. 2017h. Measurement of heavy metals in River Kabul at Khairabad Khyber Pakhtunkhwa, Pakistan. Journal of Entomology and Zoology Studies 5(6), 2263-2265. 